\section{A Vision for the New Millennium}

\author{
Die Welt und die Art und Weise wie wir über sie denken befinden sich in einem \\ tiefgreifenden Veränderungsprozess. Der Autor vertritt die These, dass die \\ Triebkräfte und Konsequenzen der Globalisierung einen Übergang zu einer neu- \\ en sozialen und ökonomischen Ordnung mit sich bringen. Nicht mehr Materiali- \\ en, Produktionsstandorte und Verteilung sind ihre zentralen Kennzeichen, son- \\ dern manipuliertes Leben, Netzwerke und Wissen. Dabei verändert sich \\ insbesondere die Rolle der globalen Konzerne, was eine nachhaltige Entwick- \\ lung vor neue Herausforderungen stellt.
}

Von Nigel Roome $\mathrm{t}$ is fashionable to develop scenarios as the new millennium approaches. Visions and scenarios [the art of anticipation] are replacing the science of prediction, which has fallen into disrepute as our world presents us with surprises that undermine our best plans. They are important at this moment not only because we are curious about the new era we are entering but we recognize the need to anticipate the fundamental changes taking place in our society and the economic order, as we become more global.

This paper not only develops a vision of the future and the transition we confront, but it suggests, that the way we think about the world is changing. This vision builds on underlying trends in society to develop a picture of the future and its implications for the governance of society and, in particular, the governance of business.

\section{A systems perspective}

The world and how we understand it are in transition. I use an open systems perspective in this paper. Here change is a representation of movement in dynamic open systems. Whether at a global or local scale these systems include biological and physical systems and human systems. These systems are dynamic, complex and interconnected. Events, however caused, in one system can combine with a range of other factors to generate changes in other systems. Whether ultimate change is large or small is difficult to predict because complex systems exist on the border of chaos and order.

The nature of open systems presents society with major issues for the governance of change. Complexity means that our knowledge of the fundamental interconnections and pathways we are dealing with is poorly developed and that change is difficult to predict. From the viewpoint of human systems we can also view the global changes we confront as the outcome of a tyranny of many small human choices. However, these choices are commonly driven by social myths or social givens - accepted within society without major critique until they are replaced by subsequent myths. Altering the pattern of human choice invariably means addressing the prevalence, power and consequence of such myths. Yet, the institutions of governance - international and national government, business and the voluntary sector - often embody and uphold these myths as part of their function and position in society.

\section{Global change and sustainability}

In terms of global change it is convenient to think of changes taking place in three human systems - the system of development, the economic and financial system, and the social and cultural system. In practice these three increasingly global systems are highly interconnected and interwoven with the physical and ecological systems of the planet. We can regard the agenda for sustainable development as a governance response to the global problems of development experienced in both the developed and developing world. This agenda was formed prior to any serious analysis of the forces of economic and financial globalization or the more recent notion of social and cultural globalization.

The main drivers and consequences of the three waves of global change are set out below in Table 1. For brevity the table is not discussed in detail. The key point is that the inter-

\begin{tabular}{|c|c|c|c|}
\hline & Global Development & Economic and Financial Globalization & Social and Cultural Globalization \\
\hline Drivers & $\begin{array}{l}\text { - Technology advance } \\
\text { - Chemical and industrial production } \\
\text { - Luxuries become commodities } \\
\text { - Financial aid for development }\end{array}$ & $\begin{array}{l}\text { - Ubiquitous information \& communication technology } \\
\text { - Micro-chips and computer power } \\
\text { - Corporate strategies aim for global span and } \\
\text { global markets } \\
\text { - Competition is global }\end{array}$ & $\begin{array}{l}\text { - Media, communications and international travel as } \\
\text { global commodities } \\
\text { - The rise of the global elite } \\
\text { - The increase in economic and political refugees seek } \\
\text { new lands } \\
\text { - Political, ethnic, religious and resource-based conflict }\end{array}$ \\
\hline $\begin{array}{l}\text { Conse- } \\
\text { quences }\end{array}$ & $\begin{array}{l}\text { - Industrial externalities } \\
\text { - Increased resource throughput, } \\
\text { resource depletion and pollution } \\
\text { - The poor have limited access to water, } \\
\text { fuel, shelter and literacy }\end{array}$ & $\begin{array}{l}\text { - Economic and financial turbulence } \\
\text { - Interaction of money and stock markets } \\
\text { in different world regions } \\
\text { - The rich become richer and the poor poorer }\end{array}$ & $\begin{array}{l}\text { - The emergence of global brands } \\
\text { - Global culture } \\
\text { - Multi-culturalism } \\
\text { - Fragmenting social, community and individual } \\
\text { identities } \\
\text { - Fundamentalism as the basis for identity } \\
\text { - Consumption as the basis for identity } \\
\text { - Social and environmental alienation }\end{array}$ \\
\hline
\end{tabular}


connections between the three waves of global change reinforce and amplify the trends in each wave.

The interweaving forces of change provoke uncertain and contested future(s), in which we find it more and more difficult to anticipate and agree outcomes. And where the pace of change outstrips our attempts at governance and restraint. For example, many aspects of Agenda 21 are already overtaken by new events such as the growth in global trade and the mass movement of peoples - despite the fact that it still has to be fully implemented. Not only does each form of change demand new approaches to governance; the overall problem set of global change combining development, economic and financial and socio-cultural change demands a coherent and concerted response.

\section{Transitions}

Given this background I contend that we are engaged in transition from one social and economic order to another. As with all transitions, our experience of these changes is not yet well formed and our ability to see and describe what is taking place is not clear. Here I attempt to capture some dimensions of this transition, especially as it relates to the increasingly powerful position of corporations. Some of the main characteristics of the past/present and future worlds that are linked to global change are identified in Table 2.

Table 2 should also be read for content. I want to pick up the main issues in the text. I argue that we are moving from an industrial world, organized around sites of production where materials are converted into products through chemical and engineering processes, toward a world based on the manipulation of biological matter and natural systems that distributes information and services through networks. We are moving from a world of 'materials, manufacturing sites and distribution' to a world of 'manipulated being, networks and knowing'. At present both worlds co-exist and will continue to do so until the new biological and information technologies take on a progressively more dominant position. This transition is being driven by the factors set out in Table 1.

\section{Changing myths}

Importantly the present and the future are informed by different myths. The myths of the past/present world were located in the tension between industry and the industrial state. Tech-

\begin{tabular}{|c|c|c|}
\hline \multicolumn{3}{|c|}{ Table 2: Worlds in Transition } \\
\hline Past/present World & Aspects of Transition & Fufure World \\
\hline $\begin{array}{l}\text { A chemical, engineering industrial world } \\
\text { A world of rich and poor, developed and less developed } \\
\text { A world of organizations and hierarchy } \\
\text { - A world of 'materials, manufacturing sites \& distribution' }\end{array}$ & Description & $\begin{array}{l}\text { - A biological and information world } \\
\text { - A world of life-style, imoges, aspirations \& poverty } \\
\text { - A world of systems and networks } \\
\text { - A world of 'manipulated nature, networks and being' }\end{array}$ \\
\hline $\begin{array}{l}\text { - The state as an important agent and regulator of the industrial } \\
\text { economy \& society } \\
\text { - Increasing GNP equates to social well-being \& derives from } \\
\text { industrial activity and the production of goods } \\
\text { Industrial \& technological development is isolated from its } \\
\text { social \& environmental consequences } \\
\text { Developing countries should borrow to follow the path of the } \\
\text { developed world. They require industrial, economic \& financial } \\
\text { infrastructure the same as developed countries }\end{array}$ & Myths & $\begin{array}{l}\text { - Individualism \& corporate capitalism are unassailable. } \\
\text { The state is reinvented and state industrial } \\
\text { enterprise is deregulated in the interests of consumers } \\
\text { Open, free, global markets are supreme and global growth, } \\
\text { global production and global markets are the } \\
\text { route to economic and social well-being } \\
\text { - Western life-styles and consumer patterns } \\
\text { are global icons \& role models } \\
\text { - Tele-visual and Internet images reflect the real world }\end{array}$ \\
\hline $\begin{array}{l}\text { The nation and municipal state os the countervailing } \\
\text { force to the power of the corporation }\end{array}$ & Power & $\begin{array}{l}\text { A diminishing national and municipal state. The rise } \\
\text { of the corporation and the institutions of global governance }\end{array}$ \\
\hline $\begin{array}{l}\text { Process technologies, chemical and engineering } \\
\text { plant, transport, automobiles and robotics }\end{array}$ & Technologies & $\begin{array}{l}\text { Digital, information, communications, } \\
\text { computing and biological and genetic engineering }\end{array}$ \\
\hline $\begin{array}{l}\text { - Resource-bose } \\
\text { Main sectors food, oil, consumer electronics, automobiles } \\
\text { - Technology and manogement } \\
\text { - Products \& brands } \\
\text { - Supplier relationships }\end{array}$ & $\begin{array}{l}\text { Competitive Areas } \\
\text { for Business }\end{array}$ & $\begin{array}{l}\text { Ownership of notural and human systems } \\
\text { (eg: water, energy, biological genome) } \\
\text { Main sectors eg: food \& nutrition, energy, } \\
\text { information \& communication systems } \\
\text { Patents \& means of ownership } \\
\text { Knowledge workers } \\
\text { - Service \& partnership relationships }\end{array}$ \\
\hline $\begin{array}{l}\text { - Price and product differentiation } \\
\text { - Market share } \\
\text { - Global production and soles } \\
\text { - Externalities of production } \\
\text { - Entry into new markets through strategic allionces } \\
\text { - Efficiency of production and cost control }\end{array}$ & Issues & $\begin{array}{l}\text { - Information control } \\
\text { - Ownership of systems } \\
\text { - Global presence \& local acceptability } \\
\text { - Competition with new sectors and with } \\
\text { other interests (civil or governmental) } \\
\text { - Legitimacy }\end{array}$ \\
\hline $\begin{array}{l}\text { Markets allocate goods and services } \\
\text { The economics of externalities } \\
\text { - The problems of poverty, literacy and health }\end{array}$ & Anolytical Frame & $\begin{array}{l}\text { - Ownership and governance of information } \\
\text { Ownership and governance of 'systems' } \\
\text { Ownership and governance of corporations }\end{array}$ \\
\hline
\end{tabular}


nological innovation and industrial development were universally accepted as the key to social well - being and provided a model for the world to imitate. Tangible artefacts - factories, ports, radios, automobiles - informed our myths. These provided value. They were signs of progress. Our new, unfolding myths are based in the ground between the sovereignty of the individual to choose, the right of the corporation to advance in a free market, and the responsibility of the state to re-invent by becoming progressively smaller and more businesslike. This new mythology is increasingly informed by the virtual and meta-physical - we deify life-style, based not on artefacts but on brands, labels and image. Our 'experience' of the world is progressively expanded by a myriad of electronic images and places we visit rather than an intimate knowledge of where we live. We value virtual communities and visual images. Options, futures and derivatives have more value than commodities.

\section{The rising power of corporations}

We are experiencing a radical redistribution of power which is moving away from nation states and municipalities toward the private sector, and from the local and national level to the regional and international level. Multi-national corporations are increasing in power at the same time their technological base is shifting from chemical and industrial processes to the new technologies of information, communications, computing and the manipulation of biological material.

This will open up new areas for competition and, because of the power of corporations, these areas of competition will provoke sites of conflict in our society. The focus of competition will move from materials and products to technological know how and the ownership of biological materials and natural systems. For example, companies will increasingly want to patent the new biological material that they are able to generate through genetic engineering and manipulation. Companies will also come to see the ownership of natural systems as fundamental to their economic survival. Companies will seek to take ownership of important systems such as water, food and nutrition, energy, information and communications, the biological genome and household services. Natural cycles, such as carbon and nitrogen, will become part of the global market system.
Multi-nationals will compete to own and manage these systems. For example, as potable water becomes scarcer so water companies and corporation such as Coca-Cola will want to take ownership of watersheds. Others will align themselves with whole systems, for example, Nestlé and Unilever will move from being food companies to food and nutrition systems companies. They will begin to exert influence down the whole supply chain, around issues like agricultural production and fisheries management as well as organizing the food processing system. Here, too, there will be opportunities for genetic manipulation as the foodstuffs are 'enhanced' in their nutrition content through genetic modification. Oil companies such as Shell will first define themselves as energy supply companies but will soon identify themselves as energy systems service companies, concerned with both the supply and demand-side of energy services.

\section{New issues}

A new range of issues will emerge as corporations take on the ownership of systems. The focus of these issues will be the ability of corporations to govern decentralized and dispersed natural systems. And, the problem that the market is only able to allocate the services of natural systems on the basis of people's ability to pay rather than on an assessment of a citizens fundamental rights or needs for the services of those systems. This will mean that companies will face an issue of legitimacy as they find themselves less and less able to govern the allocation of 'system services' in ways that meets the full range of interests of those with a stake in those systems. At the same time the demands for those 'system services' will increase under the pressure of population and the growth of a larger and more vocal middle-class.

This implies a radical change in the way we define and analyze markets and market systems. For the last 75 years we have developed a sophisticated language about the 'externalities' of industrial manufacturing and production. Increasingly it has been recognized that these externalities need to be 'internalized' in some way or another and policies have been institutionalized. However, the issue of externalities, that has preoccupied us, will be replaced by more fundamental questions about ownership, and the rights and responsibilities that go with ownership, as corporations appropriate systems for their own ends. The crisis of systems own- ership is that it creates sites of conflict and provokes fault lines in the practice of corporate governance: the interests of shareholders will be at odds with the interests of others who have a direct stake in the systems increasingly taken into corporate ownership.

\section{- Implications}

What this future world means for sustainable development is hard to predict. The private ownership of natural systems is not in itself the issue, although the move toward the manipulation of genetic material raises profound questions about how to manage the 'unknowability' of the potential changes this might provoke in biological systems. In this case we should view genetic engineering as a huge social and biological experiment. In this brave new world of socially constructed science there is no longer a clear division between scientist and experiment. The two become so blurred that society and the natural world together make up the experiment, the world as laboratory containing both experiment and experimenter.

However, the real thrust of this paper is the idea that our present approach to governance and management in the private sector is not capable of dealing adequately with the dilemmas and problems inherent in the private ownership of natural systems. The paper explicitly seeks to raise the issue of the need to restructure governance, management and the rights and responsibilities that go with private ownership before it is overtaken by events provoked by the appropriation of biology and natural systems. Where this debate will lead us I do not know. But it is our duty as citizens to assess the implications of this world, to respond to the challenges it presents and to develop the profound social innovations that will enable us to live sustainably within that world.

\section{Der Autor}

Nigel Roome ist Professor für Sustainable Enterprise and Transformation an der Erasmus University Rotterdam

Kontakt: Faculty of Social Science, Erasmus University Rotterdam, PO Box 1738, 3000 DR Rotterdam, Niederlande. Tel. 0031-10-408-2549,

Fax-9104, E-mail: roome@fsw.eur.nl 
(c) 20I0 Authors; licensee IÖW and oekom verlag. This is an article distributed under the terms of the Creative Commons Attribution Non-Commercial No Derivates License (http://creativecommons.org/licenses/by-nc-nd/3.o/), which permits unrestricted use, distribution, and reproduction in any medium, provided the original work is properly cited. 